\title{
Application of weighted response surface methodology for enhanced poly (3-hydroxybutyrate) production by endophytic bacillus cereus RCL 02
}

\begin{abstract}
Application of statistical models in developing strategies for process optimization and enhanced product yield is well established. The present study is focused to enhance poly (3-hydroxybutyrate) [P(3HB)] production by Bacillus cereus RCL 02, a leaf endophyte of oleaginous plant Ricinus communis L. using weighted response surface methodology (WRSM). The most influencing process variables for growth and bio-polyester accumulation were initially selected through Plackett-Burman (PB) designed experiments. Further, WRSM was applied to navigate the experimental data obtained in accordance with the central composite design (CCD). Interaction of three independent variables viz. carbon source (glucose), nitrogen source (yeast extract) and initial $\mathrm{pH}$ of the medium exerted most significant impact on biomass formation as well as $\mathrm{P}(3 \mathrm{HB})$ production. A second order polynomial equation obtained from multiple regression analysis and the interaction studies from surface plots helped to determine the optimum concentrations of glucose $(25 \mathrm{~g} / \mathrm{L})$, yeast extract $(4 \mathrm{~g} / \mathrm{L})$ and initial $\mathrm{pH}$ (7.6). Validation of this statistical model was executed using point prediction tool of WRSM where-from the optimum values of all three significant variables were employed and experiments were conducted. Under such optimized conditions the endophytic isolate produced $8.07 \mathrm{~g} / \mathrm{L}$ of $\mathrm{P}(3 \mathrm{HB})$, which was very close to the predicted value $(7.80 \mathrm{~g} / \mathrm{L})$ and thereby validated the model. Finally, the identity of the intracellularly accumulated bio-polyester of $B$. cereus RCL 02 was confirmed by proton nuclear magnetic resonance (1H NMR) spectroscopic analysis.
\end{abstract}

Volume 5 Issue I - 2018

\author{
Rituparna Das,' Arundhati Pal, ${ }^{2}$ Ganesh \\ Dutta, ${ }^{3}$ Maiti DK, ${ }^{4}$ Paul AK' \\ 'Department of Botany, University of Calcutta, India \\ ${ }^{2}$ Department of Botany, Serampore College, India \\ ${ }^{3}$ Department of Statistics, Basanti Devi College, India \\ ${ }^{4}$ Department of Chemistry, University of Calcutta, India
}

Correspondence: Paul AK, Department of Botany, Microbiology Laboratory, University of Calcutta, Kolkata 700 019,West Bengal, India, Fax 91033246 I 4849, Tel 9 । 9830905580,Email amalk_paul@yahoo.co.in Received: November 19, 2017 | Published: February 14,
2018

Keywords: process optimization, bacillus cereus, bio-polyester, ricinus communis 1, polyoxoesters, thermoplastics

Abbreviations: $\mathrm{P}(3 \mathrm{HB})$, poly (3-hydroxybutyrate); WRSM, weighted response surface methodology; $\mathrm{PB}$, plackett-burman; $\mathrm{CCD}$, central composite design; NMR, nuclear magnetic resonance; PHAs, polyhydroxyalkanoates; OVAT, one variable at a time; RSM, response surface methodology; DoE, design of experiment

\section{Introduction}

Research on biodegradable biopolymers has been increasing rapidly during the past few decades due to the environmental concerns related to plastic pollution. Polyhydroxyalkanoates (PHAs), the structurally versatile, biodegradable polyoxoesters produced by diverse group of microorganisms as intracellular storage granules have material properties similar to thermoplastics and identified as a promising substitute for conventional petrochemical plastics. The biosynthesis, biodegradation, physico-chemical properties, application and biological functions of poly (3-hydroxybutyrate) [P(3HB)], the most common PHA have been extensively studied. ${ }^{1}$ Despite huge potential for eco-benign applications, $\mathrm{P}(3 \mathrm{HB})$ could not gain substantial consideration due to its low yield and expensive production cost. To make the PHA based bioplastic production economically viable and competitive with petroleum based thermoplastics, constant efforts are being made to find newer high-yielding microbial strains, relatively cheaper substrates and also to develop low-cost production strategies.

Media formulation and process optimization are important steps in bio-processing using a potent microbial strain as it significantly influence the product yield as well as cost. Significant enhancement in $\mathrm{P}(3 \mathrm{HB})$ production involves precise expression of kinetic model along with the optimum physico-chemical parameters. The statistical model is capable of analyzing data and creating a strategy to resolve fermentation as well as product formation issues. Moreover, it provides information about fermentation process parameters to increase production efficiency of a particular strain. Process optimization for $\mathrm{P}(3 \mathrm{HB})$ production by conventional single dimension 'one variable at a time' (OVAT) approach is laborious and time consuming, especially for a large number of variables, and does not ensure the determination of exact optimal conditions. Therefore, statistics based experimental designs have gained importance as economic and practical solutions for process optimization of various biomaterial production including $\mathrm{P}(3 \mathrm{HB})$. Plackett-Burman $(\mathrm{PB})$ design is a quick screening procedure which mathematically computes the importance of large number of variables in fewer experiments. The selected variables are then optimized subsequently by design of experiment (DoE) approach based on central composite design (CCD) of response surface methodology (RSM). It is a kind of statistical technique for designing experiments, evaluating the relative significance of several independent variables and determining the optimum conditions for desirable responses. Although, it is difficult to analyze the results obtained from RSM when several dependent variables (responses) of interest are involved making the optimization procedure a challenging one. Interrelationships that may exist among the responses can render univariate investigation purposeless. 
$\mathrm{P}(3 \mathrm{HB})$ production by various Bacillus spp. has been thoroughly investigated. ${ }^{2,3}$ There are several reports on statistical optimization of different process parameters for growth and $\mathrm{P}(3 \mathrm{HB})$ production. ${ }^{4,5}$ However, none of these documentations have focused attention on the existence of mathematical correlation between the two responses. Futile separate individual optima may be obtained by optimizing these two correlated responses [growth and $\mathrm{P}(3 \mathrm{HB})$ production] simultaneously. It is also apparent that exact optimal conditions for growth may not coincide with the optimal conditions for the biopolyester production and hence production may not be satisfactory. Thus, if correlations among these variables are ignored, the designers may overlook the design variable settings that simultaneously improve the quality of both responses which in-turn could lead to an unsatisfactory result causing model instability, over-fitting and errors of prediction. Since biomass formation and $\mathrm{P}(3 \mathrm{HB})$ production are highly correlated, these two responses can be combined into single response giving equal weights, and can be established as weighted response (W) as a representative of the two individual responses using weighted response surface methodology (WRSM) along with desirability function. The application of this new hybrid method is likely to improve the predictive accuracy of the model over the individual one.

Mostly $\mathrm{P}(3 \mathrm{HB})$ production studies have been confined to Gramnegative bacteria with fewer reports on Gram-positive ones. As the $\mathrm{P}(3 \mathrm{HB})$ derived from Gram-positive bacteria is free from endotoxins, it may have preferred potential in biomedical application. However, large scale production of $\mathrm{P}(3 \mathrm{HB})$ by Gram-positive bacteria including Bacillus spp. has been met with limited success so far. Though, few reports on the optimization of process parameters for $\mathrm{P}(3 \mathrm{HB})$ production has been documented ${ }^{6-8}$ detailed studies on the correlation of nutritional components and environmental factors favouring higher yield is essentially required. The carbon to nitrogen ratio as well as the $\mathrm{pH}$ of the medium exert significant influence on the synthesis and accumulation of $\mathrm{P}(3 \mathrm{HB})$. The WRSM is an efficient tool to study the interactive effect of such process parameters involved in fermentation seeking optimized conditions for improved product yield.

The present study is an attempt to optimize the physico-chemical process parameters and nutritional factors for $\mathrm{P}(3 \mathrm{HB})$ production by Bacillus cereus RCL 02, a leaf endophyte of oleaginous plant Ricinus communis L., through statistical approach for its possible wide range application. To the best of our knowledge, this study is the first report in establishing linear mathematical relationship between biomass formation and $\mathrm{P}(3 \mathrm{HB})$ production by Bacillus cereus RCL 02 based on weighted response surface methodology (WRSM).

\section{Materials and methods}

\section{Bacterial strain and culture condition}

Bacillus cereus RCL 02 (GenBank accession no. KX458035; MCC 3436), isolated previously from leaf tissues of oleaginous plant $R$. communis L. was used in this study. The culture was grown on slopes of tryptic soy agar at $32^{\circ} \mathrm{C}$ for $24 \mathrm{~h}$ and maintained by regular subculturing on the same medium. For growth and $\mathrm{P}(3 \mathrm{HB})$ accumulation, modified mineral salts medium ${ }^{9}$ was used throughout this study.

\section{Estimation of growth}

Cells from the growing culture were harvested by centrifugation $(10,000 \mathrm{xg}$ for $10 \mathrm{~min})$, washed thoroughly with deionized water and the dry weight of the biomass was determined by drying the cell mass to a constant weight at $80^{\circ} \mathrm{C}$.

\section{Extraction and quantification of $\mathrm{P}(3 \mathrm{HB})$}

The $\mathrm{P}(3 \mathrm{HB})$ content of the dried biomass was extracted in warm chloroform ${ }^{9}$ and recovered by precipitation with chilled diethylether. The dried polymer thus recovered was treated with concentrated $\mathrm{H}_{2} \mathrm{SO}_{4}$ in a boiling water bath for $10 \mathrm{~min},{ }^{10}$ cooled to room temperature and the absorbance was recorded at $235 \mathrm{~nm}$ using a UV-VIS spectrophotometer (Jenway, Model 6505). The amount of $\mathrm{P}(3 \mathrm{HB})$ was quantified from the calibration curve prepared in the same way using authentic $\mathrm{P}(3 \mathrm{HB})$ from Sigma, USA.

\section{Experimental design and optimization using WRSM}

MINITAB (version 16, Minitab Inc., USA) software generated statistically designed experiments were performed for optimization of process parameters for growth $\left(\mathrm{Y}_{1}\right)$ and $\mathrm{P}(3 \mathrm{HB})$ production $\left(\mathrm{Y}_{2}\right)$. Plackett-Burman (PB) design was employed for selecting the process parameters having most significant influence on growth and $\mathrm{P}(3 \mathrm{HB})$ production. A total of 11 fermentation variables (with minimum and maximum levels) i.e. glucose $(10-40 \mathrm{~g} / \mathrm{L})$, yeast extract $(1-5 \mathrm{~g} / \mathrm{L})$, incubation time $(40-64 \mathrm{~h}), \mathrm{pH}$ (5.6-7.6), temperature $\left(25-35^{\circ} \mathrm{C}\right)$, inoculum volume $(1-4 \%, \mathrm{v} / \mathrm{v}), \mathrm{Na}_{2} \mathrm{HPO}_{4}(5-10 \mathrm{~g} / \mathrm{L}), \mathrm{KH}_{2} \mathrm{PO}_{4}(1-5 \mathrm{~g} /$ $\mathrm{L}), \mathrm{MgSO}_{4}(0.5-2 \mathrm{~g} / \mathrm{L}), \mathrm{MnCl}_{2}(1-4 \mathrm{mM})$ and agitation $(80-120 \mathrm{rpm})$ were selected for analyzing their influence on growth and $\mathrm{P}(3 \mathrm{HB})$ production. Selection of the fermentation variables and their lower and higher levels were decided based upon the results obtained from 'OVAT' experiments. ${ }^{11}$ Growth $\left(\mathrm{Y}_{1}\right)$ and $\mathrm{P}(3 \mathrm{HB})$ production $\left(\mathrm{Y}_{2}\right)$ were executed in a set of 12 experiments following the PB design. The significance level ( $p$ value) of each variable was determined using Fisher's F-test. Each experiment was carried out in five sets and represented as mean \pm standard deviation (SD). A strong linear relationship was observed between $\mathrm{Y}_{1}$ and $\mathrm{Y}_{2}$ [Pearson correlation coefficient $(r)=0.951098]$. The correlation between $\left(Y_{1}+Y_{2}\right) / 2$ and $\mathrm{Y}_{1}(0.989125)$ as well as $\left(\mathrm{Y}_{1}+\mathrm{Y}_{2}\right) / 2$ and $\mathrm{Y}_{2}(0.986185)$ were found very high and hence considered as a weighted response $\left[\mathrm{W}=\left(\mathrm{Y}_{1}+\mathrm{Y}_{2}\right) / 2\right]$ of the two dependent variables $Y_{1}$ and $Y_{2}$.

A total of four variables i.e. glucose, yeast extract, temperature and $\mathrm{pH}$ were recognized to have the most significant effect on growth, $\mathrm{P}(3 \mathrm{HB})$ production as well as weighted response (W) from PBdesigned experiments. They were optimized using central composite design (CCD) of WRSM to determine the most suitable conditions for maximal $\mathrm{P}(3 \mathrm{HB})$ production. The three variables (glucose, yeast extract and $\mathrm{pH})$ were used at five coded levels $(-1.6,-1,0,+1,+1.6)$ and temperature was considered as the block parameter.

All 40 experiments, generated based on the CCD design were run in five sets and the responses viz. growth $\left(\mathrm{Y}_{1}\right)$ and $\mathrm{P}(3 \mathrm{HB})$ production $\left(\mathrm{Y}_{2}\right)$ were represented as the mean $\pm \mathrm{SD}$. As in $\mathrm{PB}$ design, the CCD design also revealed a strong linear relationship between $Y_{1}$ and $\mathrm{Y}_{2}$ with a Pearson correlation coefficient $(\mathrm{r})=0.950028$. Here also the correlation between $\mathrm{W}\left[\left(\mathrm{Y}_{1}+\mathrm{Y}_{2}\right) / 2\right]$ and $\mathrm{Y}_{1}(0.988842)$ as well as $\mathrm{W}\left[\left(\mathrm{Y}_{1}+\mathrm{Y}_{2}\right) / 2\right]$ and $\mathrm{Y}_{2}(0.98593)$ were very high. Hence, CCD was employed for selecting the process parameters having most significant influence on the weighted response (W). A second-order polynomial function was fitted to correlate relationship between independent variables and response $\mathrm{W}=\left(\mathrm{Y}_{1}+\mathrm{Y}_{2}\right) / 2$ for predicting the optimal condition. The regression equation is given below as: 


$$
W=3.6548+0.2498 T+0.3464 X_{1}+1.1800 X_{2}+1.0879 X_{3}+0.6539 X_{1} X_{2}+0.5752 X_{1} X_{3}+0.7071 X_{2} X_{3}-0.8631\left(X_{1}\right)^{2}+0.2109\left(X_{2}\right)^{2}+0.4728\left(X_{3}\right)^{2}
$$

Where, $\mathrm{W}$ is the weighted response, $\mathrm{T}$ is the temperature (block parameter) and $\mathrm{X}_{1}, \mathrm{X}_{2}$ and $\mathrm{X}_{3}$ are three independent variables representing glucose, yeast extract and $\mathrm{pH}$ respectively.

\section{Data analysis}

The quadratic model was represented as three dimensional response surface plots based upon the regression equation. The response surface graphs were used to identify the effects of linear, quadratic and interactive terms of the independent variables on the chosen dependent variables. To validate the model, each response [growth and $\mathrm{P}(3 \mathrm{HB})$ production] was determined under optimized condition in 10sets of experiments. Statistical analysis of the model was evaluated by analysis of variance (ANOVA) and the significance of the model was determined by Fischer's $F$ test and the level of significance was represented as $p$ value.

\section{'H NMR spectral analysis}

The purified polyester was dissolved in deuterochloroform $\left(\mathrm{CDCl}_{3}\right)$ and subjected to ${ }^{1} \mathrm{H}$ NMR $(300 \mathrm{MHz})$ in a Bruker AV300 Supercon NMR spectrophotometer. The chemical shift-scale was in parts per million. Tetramethylsilane $\left(\mathrm{Me}_{4} \mathrm{Si}\right)$ was used as the internal standard. ${ }^{12}$ The structure of the polyester was established through analysis of recorded ${ }^{1} \mathrm{H}$ NMR spectra.

\section{Results and discussion}

\section{Selection of significant variables for $\mathrm{P}(3 \mathrm{HB})$ production based on PB-design}

Prior to optimization, Plackett-Burman (PB) designed experiments were performed in selecting significant variables for attaining higher $\mathrm{P}(3 \mathrm{HB})$ production. Among the total 11 independent variables investigated based on $\mathrm{PB}$-designed experiments, temperature, glucose, yeast extract, incubation time, $\mathrm{pH}, \mathrm{MgSO}_{4}$ and agitation were found to exert significant influence on growth as well as $\mathrm{P}(3 \mathrm{HB})$ production (Table 1). Inoculum volume, $\mathrm{Na}_{2} \mathrm{HPO}_{4}, \mathrm{KH}_{2} \mathrm{PO}_{4}$ and $\mathrm{MnCl}_{2}$ were considered together as residual errors since mean sum of squares of these variables were significantly low (Table 2). Moreover, growth $\left(\mathrm{Y}_{1}\right)$ and $\mathrm{P}(3 \mathrm{HB})$ production $\left(\mathrm{Y}_{2}\right)$ showed a strong linear relationship with a Pearson correlation coefficient $(\mathrm{r})=0.951098$. According to Ribeiro et al., ${ }^{13}$ if the Pearson correlation coefficient (r) between two variables in a multiple response system is $\geq 0.6$, then it can be considered that the corresponding variables have high degree of linear association. Here, the correlation between $\left(\mathrm{Y}_{1}+\mathrm{Y}_{2}\right) / 2$ and $\mathrm{Y}_{1}$ $(0.989125)$ and $\left(\mathrm{Y}_{1}+\mathrm{Y}_{2}\right) / 2$ and $\mathrm{Y}_{2}(0.986185)$ were found very high and hence considered as a weighted response (W) of the two dependent variables $\mathrm{Y}_{1}$ and $\mathrm{Y}_{2}$. The response $\mathrm{W}\left[\left(\left(\mathrm{Y}_{1}+\mathrm{Y}_{2}\right) / 2\right]\right.$ was expressed as the representative of two individual responses $\left(\mathrm{Y}_{1}\right.$ and $\left.\mathrm{Y}_{2}\right)$ giving equal weights. Variables having probability value ( $p$-value) less than 0.05 indicated significant effects on the response W. Evaluation of results from $\mathrm{PB}$ designed experiments showed that yeast extract with a $p$-value of zero ( 0 ) was the most significant one followed by glucose $(0.007)$, temperature $(0.028)$ and $\mathrm{pH}(0.040)$ and the optimum levels of these four independent variables were further determined by CCD model of RSM keeping the other variables at fixed level.

\section{Optimization of selected variables by WRSM}

The experimental design matrix based on CCD model of RSM was used for determining the optimum levels of the four significant variables for growth $\left(\mathrm{Y}_{1}\right)$ and $\mathrm{P}(3 \mathrm{HB})$ production $\left(\mathrm{Y}_{2}\right)$ obtained from $\mathrm{PB}$ designed experiments. The three variables (glucose, yeast extract and $\mathrm{pH})$ were used at five coded levels $(-1.6,-1,0,+1,+1.6)$ and temperature was considered as the block parameter (Table 3 ). From the results, it was clearly evident that $\mathrm{P}(3 \mathrm{HB})$ production $\left(\mathrm{Y}_{2}\right)$ increased from $6.13 \mathrm{~g} / \mathrm{L}$ in $\mathrm{PB}$ design (Table 1) to $8.03 \mathrm{~g} / \mathrm{L}$ in $\mathrm{CCD}$ experiments (Table 4).

Further, the CCD experiments also revealed a strong linear relationship between growth $\left(\mathrm{Y}_{1}\right)$ and $\mathrm{P}(3 \mathrm{HB})$ production $\left(\mathrm{Y}_{2}\right)$ [Pearson correlation coefficient $(r)=0.950028]$. As the analysis of data from a multi-response experiment requires substantial inclusion of every evaluated response, the response variables should not be investigated individually and independently of one another. ${ }^{14}$ Here also, the correlation between $\left(\mathrm{Y}_{1}+\mathrm{Y}_{2}\right) / 2$ and $\mathrm{Y}_{1}(0.988842)$ as well as $\left(\mathrm{Y}_{1}+\mathrm{Y}_{2}\right) / 2$ and $\mathrm{Y}_{2}(0.98593)$ were found considerably high. Hence $\mathrm{CCD}$ was employed for selecting the process parameters having most significant influence on the weighted response $\mathrm{W}\left[\left(\mathrm{Y}_{1}+\mathrm{Y}_{2}\right) / 2\right]$.

Multiple regression analysis was applied for the experimental observations and the independent variables were fitted to the second order polynomial equation (mentioned in 'Materials and method' section) to assess the goodness of fit. Analysis of variance (ANOVA) for the response $\mathrm{W}$ was used to analyze the adequacy of the quadratic model based on the experimental design. The $p$ values were used to check the significance of each coefficient and the corresponding coefficient is considered to be more significant if the inferred magnitude of $p$ is small. ${ }^{15}$ The high $p$ value $(0.368)$ of the block variable clearly indicated that temperature did not exert significant effect on the response (W) and hence was not considered further (Table 5). Experimental data fitted to the model were supported by the multiple correlations co-efficient $\left(\mathrm{R}^{2}\right)$ and the correlation of determination (adjusted $\mathrm{R}^{2}$ ). The high $\mathrm{R}^{2}$ value $(89.08 \%)$ and adjusted $\mathrm{R}^{2}(84.97 \%)$ of the polynomial model indicated that the model was in reasonably good agreement (Figure 1). $\mathrm{R}^{2}$ value is attributed to the proportion of variation in the response and should be $>80 \%$ for a good agreement. ${ }^{8}$ Here, the $\mathrm{R}^{2}$ value revealed that there can be $84.97 \%$ of variability in the response which can be explained by the model.

In order to determine the optimal levels of the interacting variables for maximum response, three-dimensional response surface plots were constructed by plotting the individual responses [growth $\left(\mathrm{Y}_{1}\right) / \mathrm{P}(3 \mathrm{HB})$ production $\left(\mathrm{Y}_{2}\right)$ / weighted response $(\mathrm{W})$ ] on the $\mathrm{Z}$-axis against any two selected independent variables within their experimental range while holding the other variable at fixed value. The $3 \mathrm{D}$ response surface plots are generally the graphical representation of the regression equation and the interaction between the variables can be inferred from the shapes of the surface plots. ${ }^{4}$ The surface plots for growth $\left(\mathrm{Y}_{1}\right), \mathrm{P}(3 \mathrm{HB})$ production $\left(\mathrm{Y}_{2}\right)$ and the resultant weighted response $\mathrm{W}$ showing the interactive effect of selected process variables (glucose, yeast extract and $\mathrm{pH}$ ) were studied in detail for all possible combinations (Figure 2). 
The response surface plots (Figure 2AI, 2BI \& 2CI) depict the interaction of yeast extract and glucose for biomass formation, $\mathrm{P}(3 \mathrm{HB})$ production and the resultant response $\mathrm{W}$ respectively. It has clearly reflected that biomass formation and biopolyester accumulation increased with increasing concentration of complex nitrogen source (yeast extract) and glucose up to $5 \mathrm{~g} / \mathrm{L}$ and $30 \mathrm{~g} / \mathrm{L}$ respectively. However, further increase of these two process variables decreased the polymer content. Figure 2AII, 2BII \& 2CII represent the interactive effect of glucose and initial $\mathrm{pH}$ on the three dependent response variables $\left(\mathrm{Y}_{1}\right.$, $\mathrm{Y}_{2}$ and $\left.\mathrm{W}\right)$. Enhanced intracellular $\mathrm{P}(3 \mathrm{HB})$ accumulation was clearly observed at $35 \mathrm{~g} / \mathrm{L}$ glucose concentration with an initial $\mathrm{pH}$ of 7.4 . Further increase of glucose and initial $\mathrm{pH}$ of the medium exerted negative impact on $\mathrm{P}(3 \mathrm{HB})$ production which is represented by the convergence of the curve towards boundary of the 3D plot. Response plots (Figure 2AIII, 2BIII \& 2CIII) representing interactive effect of the $\mathrm{pH}$ and yeast extract concentration confirmed the findings that responses $\left(\mathrm{Y}_{1}, \mathrm{Y}_{2}\right.$ and $\left.\mathrm{W}\right)$ were maximum with significantly high amount of yeast extract and an initial $\mathrm{pH}$ of 7.2. Such high amount of intracellular biopolyester accumulation with increasing concentration of complex nitrogen source like yeast extract corroborated well with the previous findings of Page ${ }^{16}$ where, complex nitrogen sources such as fish peptone, protease peptone, yeast extract, casitone, phytone and tryptone were found to enhance the $\mathrm{P}(3 \mathrm{HB})$ production in Azotobacter vinelandii UWD. Similarly, influence of glucose, peptone and $\mathrm{pH}$ on growth as well as $\mathrm{P}(3 \mathrm{HB})$ production by $B$. mycoides $\mathrm{DFC} 1$ has been reported by Aarthi et al. ${ }^{17}$

Different statistical approaches have been used to optimize $\mathrm{P}(3 \mathrm{HB})$ production from wide variety of bacteria. Plackett-Burman designed experiments showed that inoculum concentration, incubation time and xylose concentration had a positive effect, and inoculum age and incubation temperature had a negative impact on $\mathrm{P}(3 \mathrm{HB})$ production from acid pre-treated rice straw hydrolysate by $B$. firmus NII 0830. Further, Box-Behnken design based optimization of inoculum concentration and incubation time resulted in maximum $\mathrm{P}(3 \mathrm{HB})$ yield $(1.697 \mathrm{~g} / \mathrm{L})$. Four medium variables viz., pulp industry waste, tamarind kernel powder, palm jaggery and green gram flour were identified most influencing to attain $\mathrm{P}(3 \mathrm{HB})$ production of $19.08 \mathrm{~g} / \mathrm{L}$ by $B$. subtilis based on CCD of RSM. ${ }^{18}$ Four-factor central composite rotatable design (CCRD) was used for optimization of dairy waste, rice bran, sea water and $\mathrm{pH}$ and $\mathrm{P}(3 \mathrm{HB})$ yield of $6.37 \mathrm{~g} / \mathrm{L}$ was finally achieved from Bacillus megaterium SRKP-3. ${ }^{19}$ Temperature, $\mathrm{pH}$ and agitation speed along with cane molasses and urea as carbon and nitrogen sources, respectively were optimized based on CCRD and $8.8 \mathrm{~g} / \mathrm{L}$ of $\mathrm{P}(3 \mathrm{HB})$ was obtained from Alcaligenes $s p .^{20}$

\section{Determination of optimum condition by desirability function}

The optimum values of the independent variables for maximum biopolyester production were obtained from desirability function approach. This function transformed the estimated response variable (W) into a desirability value $d$. The values of $d$ vary in the interval $0 \leq \mathrm{d} \leq 1$ and increases as the desirability of the corresponding response increases. Thus, in order to optimize $\mathrm{W}$ score, the value of $d$ is calculated, that was prioritized by specifying the maximum and minimum values of $\mathrm{W}$ score obtained within the experimental region. Based on the proposed upper and lower bounds, the predicted W scores (9.1) and its desirability (1.000) at optimal condition was determined. The behavior of the predicted $\mathrm{W}$ was generated from the optimized factor of $25 \mathrm{~g} / \mathrm{L}$ glucose, $4 \mathrm{~g} / \mathrm{L}$ yeast extract and an initial $\mathrm{pH}$ of 7.6.

\section{Determination of predicted responses from weighted response}

For estimating the predicted values for the response growth $\left(\mathrm{Y}_{1}\right)$ and $\mathrm{P}(3 \mathrm{HB})$ production $\left(\mathrm{Y}_{2}\right)$, the linear dependencies of these responses with weighted response (W) were considered by using linear regression. The linear regression equations were as follows:

$$
\begin{aligned}
& \mathrm{Y}_{1}=-0.830+0.941 \mathrm{~W} \\
& \mathrm{Y}_{2}=0.830+1.06 \mathrm{~W}
\end{aligned}
$$

The regression coefficients in the above mentioned linear equations were significant $(p$-value $<0.05)$. These empirically developed mathematical models provide a method of linking the dependent variables growth $\left(\mathrm{Y}_{1}\right)$ and $\mathrm{P}(3 \mathrm{HB})$ production $\left(\mathrm{Y}_{2}\right)$ to the explanatory variable weighted response (W). Substituting the $\mathrm{W}$ score in the above equations, the predicted values of the original responses $\left(\mathrm{Y}_{1}\right.$ and $\left.\mathrm{Y}_{2}\right)$ were calculated and compared with the experimental data. Adjusted $\mathrm{R}^{2}$ value indicated the co-linearity between the observed and predicted results of each response. High adjR ${ }^{2}$ value $\left(97.7 \%\right.$ for $\mathrm{Y}_{1}$ and $97.1 \%$ for $\mathrm{Y}_{2}$ ) well supported the use of weighted responses as the representative of the $Y_{1}$ and $Y_{2}$ responses for correlated data in RSM.

\section{Validation and confirmation of the model}

Validation of the statistical model was executed by using point prediction tool of RSM where the optimum values of all three independent variables i.e. glucose $(25 \mathrm{~g} / \mathrm{L})$, yeast extract $(4 \mathrm{~g} / \mathrm{L})$ and initial $\mathrm{pH}$ (7.6) were employed for experimentation. The observed experimental values for growth $\left(\mathrm{Y}_{1}\right), \mathrm{P}(3 \mathrm{HB})$ production $\left(\mathrm{Y}_{2}\right)$ and weighted response (W) (mean of 10 replicates) were compared with the corresponding predicted values to ensure that the optimal conditions derived from the experiments actually enhanced the $\mathrm{P}(3 \mathrm{HB})$ production. The predicted values were realistically achieved within 95\% confidence interval of experimental values (Table 6). Furthermore, it was observed from probability plot, that the responses $\mathrm{Y}_{1}$ and $\mathrm{Y}_{2}$ including the weighted response (W) obtained under optimal experimental conditions had the normal distribution (Figure 3). Nonetheless, in the confirmatory experiment, the experimental values are in reasonable agreement within the said confidence intervals for these optimized conditions. The closeness between the experimental and predicted values of the biomass $(10.25$ and $10.55 \mathrm{~g} / \mathrm{L})$ and $\mathrm{P}(3 \mathrm{HB})$ production $(8.07$ and $7.8 \mathrm{~g} / \mathrm{L})$ also indicated the suitability of the corresponding model.

This study revealed a 2.81 -fold enhancement $(2.87$ to $8.07 \mathrm{~g} / \mathrm{L})$ of $\mathrm{P}(3 \mathrm{HB})$ production by the endophytic $B$. cereus RCL 02 after optimization using response surface methodology in comparison to the preliminary OVAT studies. ${ }^{11}$ Production of biopolyester $(8.07 \mathrm{~g} / \mathrm{L})$ by the leaf endogenous isolate $B$. cereus appeared to be quite satisfactory and compared well with other Bacillus spp. so far reported. ${ }^{6,8,17,19,21}$

\section{'H NMR spectral analysis}

The peaks in ${ }^{1} \mathrm{H}$ NMR spectrum (Figure 4) of the purified polyester were assignable to the methyl $\left(\mathrm{CH}_{3} ; 1.23-1.27 \mathrm{ppm}\right)$, methylene $\left(\mathrm{CH}_{2} ; 2.42-2.63 \mathrm{ppm}\right)$ and methine $(\mathrm{CH} ; 5.21-5.27 \mathrm{ppm})$ carbon resonance of $\mathrm{P}(3 \mathrm{HB})$ reported previously by Doi et al. ${ }^{12}$ The characteristic signals for other hydroxyalkanoic acids, however, were 
absent in the spectra and molecular composition as indicated by polyester being composed solely of 3-hydroxybutyric acid. the chemical shifts $(\delta)$ confirmed the homopolymeric nature of the

Table I Observed response for growth $\left(\mathrm{Y}_{1}\right)$ and $\mathrm{P}(3 \mathrm{HB})$ production $\left(\mathrm{Y}_{2}\right)$ by the endophytic B. cereus RCL 02 and their corresponding weighted response (W) based on Plackett-Burman designed experiments

\begin{tabular}{|c|c|c|c|c|c|c|c|c|c|c|c|c|c|c|}
\hline \multirow[b]{2}{*}{$\begin{array}{l}\text { Run } \\
\text { order }\end{array}$} & \multicolumn{9}{|c|}{ Experimental variables } & \multicolumn{5}{|c|}{ Responses } \\
\hline & $\begin{array}{l}\text { Tempe- } \\
\text { rature } \\
\left({ }^{\circ} \mathrm{C}\right)\end{array}$ & $\begin{array}{l}\text { Glucose } \\
(\mathrm{g} / \mathrm{L})\end{array}$ & $\begin{array}{l}\text { Yeast } \\
\text { extract } \\
(\mathrm{g} / \mathrm{L})\end{array}$ & $\begin{array}{l}\text { Incu- } \\
\text { bation } \\
\text { (h) }\end{array}$ & pH & $\begin{array}{l}\text { Inocu- } \\
\operatorname{lum}(\%, \\
\text { v/v) }\end{array}$ & $\begin{array}{l}\mathrm{Na}_{2} \\
\mathrm{HPO}_{4} \\
(\mathrm{~g} / \mathrm{L})\end{array}$ & $\begin{array}{l}\mathrm{KH}_{2} \mathrm{PO}_{4} \\
(\mathrm{~g} / \mathrm{L})\end{array}$ & $\begin{array}{l}\mathrm{MgSO}_{4} \\
(\mathrm{~g} / \mathrm{L})\end{array}$ & $\begin{array}{l}\mathrm{MnCl}_{2} \\
(\mathrm{mM})\end{array}$ & $\begin{array}{l}\text { Agi- } \\
\text { tation } \\
(\text { rpm) }\end{array}$ & $\begin{array}{l}\text { Growth, } \\
\text { CDW } \\
(\mathrm{g} / \mathrm{L})\left(\mathrm{Y}_{1}\right)\end{array}$ & $\begin{array}{l}\mathbf{P}(3 \mathrm{HB}), \\
(\mathrm{g} / \mathrm{L}) \\
\left(\mathbf{Y}_{2}\right)\end{array}$ & $\begin{array}{l}\text { Wei- } \\
\text { ghted } \\
\text { respon- } \\
\text { se }(W)\end{array}$ \\
\hline 1 & 25 & 40 & 1 & 40 & 5.6 & 4 & 10 & 5 & 0.5 & 4 & 200 & $\begin{array}{l}2.82 \pm \\
0.11\end{array}$ & $\begin{array}{l}0.77 \pm \\
0.04\end{array}$ & $\begin{array}{l}1.80 \pm \\
0.06\end{array}$ \\
\hline 2 & 35 & 10 & 5 & 40 & 5.6 & 1 & 10 & 5 & 2 & 1 & 200 & $\begin{array}{l}5.30 \pm \\
1.10\end{array}$ & $\begin{array}{l}3.13 \pm \\
0.97\end{array}$ & $\begin{array}{l}4.22 \pm \\
1.03\end{array}$ \\
\hline 3 & 35 & 10 & 1 & 40 & 7.6 & 4 & 10 & 1 & 2 & 4 & 80 & $\begin{array}{l}2.44 \pm \\
0.19\end{array}$ & $\begin{array}{l}0.86 \pm \\
0.04\end{array}$ & $\begin{array}{l}1.65 \pm \\
0.11\end{array}$ \\
\hline 4 & 25 & 10 & 5 & 64 & 7.6 & 1 & 10 & 5 & 0.5 & 4 & 80 & $\begin{array}{l}6.64 \pm \\
0.39\end{array}$ & $\begin{array}{l}4.46 \pm \\
0.20\end{array}$ & $\begin{array}{l}5.54 \pm \\
0.27\end{array}$ \\
\hline 5 & 25 & 40 & 5 & 40 & 7.6 & 1 & 5 & 1 & 2 & 4 & 200 & $\begin{array}{l}9.64 \pm \\
0.10\end{array}$ & $\begin{array}{l}6.13 \pm \\
0.50\end{array}$ & $\begin{array}{l}7.89 \pm \\
0.27\end{array}$ \\
\hline 6 & 25 & 10 & 1 & 40 & 5.6 & 1 & 5 & 1 & 0.5 & 1 & 80 & $\begin{array}{l}2.19 \pm \\
0.14\end{array}$ & $\begin{array}{l}1.19 \pm \\
0.16\end{array}$ & $\begin{array}{l}1.69 \pm \\
0.15\end{array}$ \\
\hline 7 & 35 & 40 & 5 & 40 & 7.6 & 4 & 5 & 5 & 0.5 & 1 & 80 & $\begin{array}{l}8.40 \pm \\
0.82\end{array}$ & $\begin{array}{l}5.24 \pm \\
1.04\end{array}$ & $\begin{array}{l}6.82 \pm \\
0.92\end{array}$ \\
\hline 8 & 35 & 40 & 1 & 64 & 7.6 & 1 & 10 & 1 & 0.5 & 1 & 200 & $\begin{array}{l}1.79 \pm \\
0.17\end{array}$ & $\begin{array}{l}0.60 \pm \\
0.05\end{array}$ & $\begin{array}{l}1.19 \pm \\
0.11\end{array}$ \\
\hline 9 & 25 & 40 & 5 & 64 & 5.6 & 4 & 10 & 1 & 2 & 1 & 80 & $\begin{array}{l}8.74 \pm \\
0.22\end{array}$ & $\begin{array}{l}4.17 \pm \\
0.31\end{array}$ & $\begin{array}{l}6.45 \pm \\
0.08\end{array}$ \\
\hline 10 & 35 & 10 & 5 & 64 & 5.6 & 4 & 5 & 1 & 0.5 & 4 & 200 & $\begin{array}{l}4.92 \pm \\
0.08\end{array}$ & $\begin{array}{l}2.37 \pm \\
0.09\end{array}$ & $\begin{array}{l}3.64 \pm \\
0.03\end{array}$ \\
\hline 11 & 25 & 10 & 1 & 64 & 7.6 & 4 & 5 & 5 & 2 & 1 & 200 & $\begin{array}{l}2.25 \pm \\
0.33\end{array}$ & $\begin{array}{l}0.89 \pm \\
0.14\end{array}$ & $\begin{array}{l}1.57 \pm \\
0.24\end{array}$ \\
\hline 12 & 35 & 40 & 1 & 64 & 5.6 & 1 & 5 & 5 & 2 & 4 & 80 & $\begin{array}{l}2.72 \pm \\
0.40\end{array}$ & $\begin{array}{l}1.60 \pm \\
0.19\end{array}$ & $\begin{array}{l}2.16 \pm \\
0.29\end{array}$ \\
\hline
\end{tabular}

Each experimental value represents the mean \pm standard deviation from 5 replicates.

Table 2 Statistical analysis of Plackett-Burman designed experiments showing $F$ and $p$ values for each variable

\begin{tabular}{lll}
\hline Variables $^{\mathrm{a}}$ & F value & p value \\
\hline Temperature $\left({ }^{\circ} \mathrm{C}\right)$ & 11.26 & 0.028 \\
Glucose $(\mathrm{g} / \mathrm{L})$ & 26.03 & 0.007 \\
Yeast extract $(\mathrm{g} / \mathrm{L})$ & 244.43 & 0 \\
Incubation $(\mathrm{h})$ & 4.98 & 0.09 \\
$\mathrm{pH}$ & 8.98 & 0.04 \\
$\mathrm{MgSO}_{4}(\mathrm{~g} / \mathrm{L})$ & 4.29 & 0.107 \\
Agitation $_{(\mathrm{rpm})}$ & 6.55 & 0.063
\end{tabular}

alnoculum $(\%, v / v), \mathrm{Na} 2 \mathrm{HPO} 4(\mathrm{~g} / \mathrm{L}), \mathrm{KH} 2 \mathrm{PO} 4(\mathrm{~g} / \mathrm{L})$ and $\mathrm{MnCl} 2(\mathrm{mM})$ were considered together as residual errors since mean sum of squares due to these variables were significantly low.

Table 3 Level of independent variables for growth and $\mathrm{P}(3 \mathrm{HB})$ production by $\mathrm{B}$. cereus $\mathrm{RCL} 02$ based on central composite design of response surface methodology

\begin{tabular}{llllll}
\hline \multirow{2}{*}{ Independent variables } & \multicolumn{7}{c}{ Coded levels } \\
\cline { 2 - 6 } & $\mathbf{- 1 . 6}$ & $\mathbf{- 1}$ & $\mathbf{0}$ & $\mathbf{1}$ & $\mathbf{1 . 6}$ \\
\hline Glucose $(\mathrm{g} / \mathrm{L})$ & 10 & 16 & 25 & 34 & 40 \\
Yeast extract (g/L) & 1 & 2 & 3 & 4 & 5 \\
$\mathrm{pH}$ & 5.6 & 6 & 6.6 & 7.2 & 7.6 \\
\hline
\end{tabular}




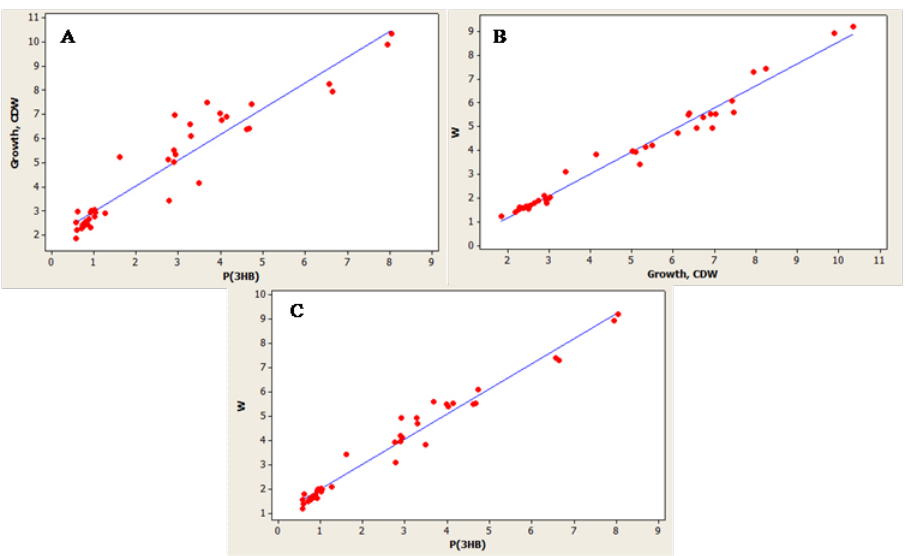

Figure I Scatter plots showing positive correlations between $(A)$ growth $\left(Y_{1}\right)$ and $P(3 H B)$ production $\left(Y_{2}\right) ;(B)$ Weighted response $(W)$ and growth $\left(Y_{1}\right)$ as well as $(\mathrm{C})$ weighted response $(\mathrm{W})$ and $\mathrm{P}(3 \mathrm{HB})$ production $\left(\mathrm{Y}_{2}\right)$
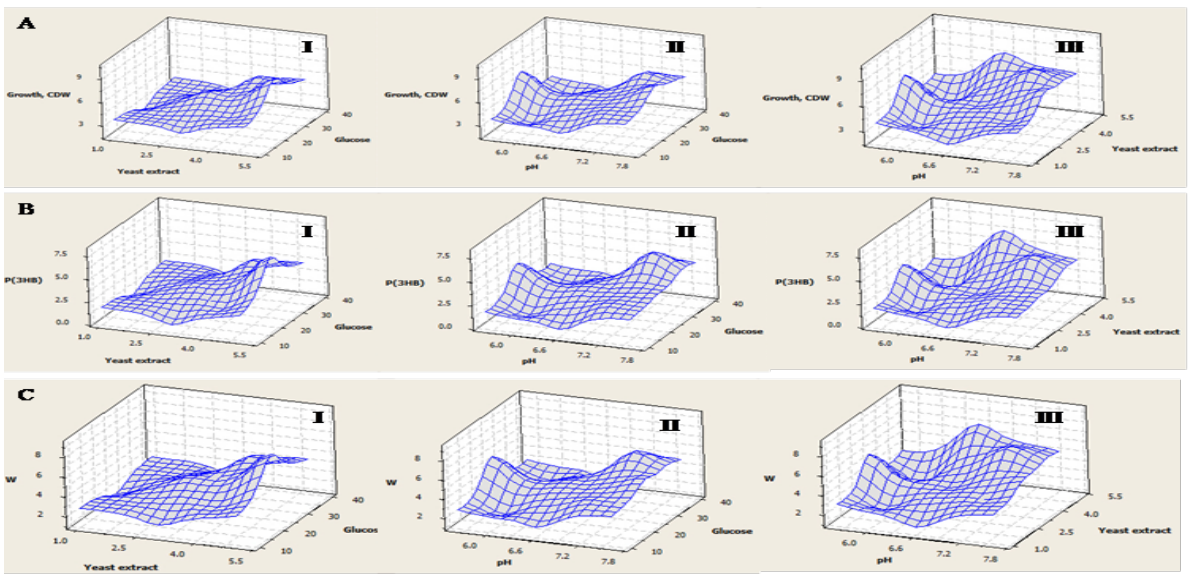

Figure 2 Response surface plots of (A) growth (YI), (B) P(3HB) production (Y2) and (C) Weighted response (W) showing the interactive effect of (I) yeast extract and glucose (II) initial $\mathrm{pH}$ and glucose as well as (III) initial $\mathrm{pH}$ and yeast extract.

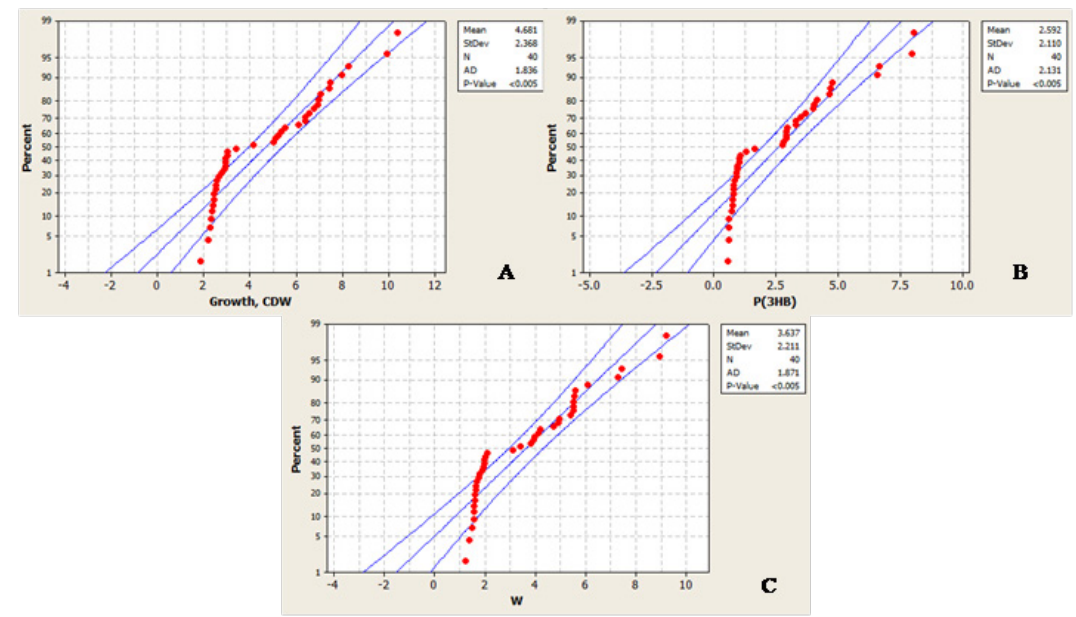

Figure 3 Probability plots of growth (YI), P(3HB) production (Y2) and weighted response (W) at 95\% confidence interval. 
Table 4 Observed response for growth $(\mathrm{YI})$ and $\mathrm{P}(3 \mathrm{HB})$ production $(\mathrm{Y} 2)$ by the endophytic $\mathrm{B}$. cereus $\mathrm{RCL} 02$ and their corresponding weighted response (W) based on central composite design of RSM

\begin{tabular}{|c|c|c|c|c|c|c|c|}
\hline \multirow[b]{2}{*}{ Run order } & \multirow{2}{*}{$\begin{array}{l}\text { Block } \\
\text { Temperature }\left({ }^{\circ} \mathrm{C}\right)\end{array}$} & \multicolumn{3}{|c|}{ Experimental variables } & \multicolumn{3}{|l|}{ Responses } \\
\hline & & Glucose $(g / L)$ & Yeast extract $(\mathrm{g} / \mathrm{L})$ & pH & Growth, CDW (g/L) $\left(Y_{1}\right)$ & $\mathrm{P}(3 \mathrm{HB}),(\mathrm{g} / \mathrm{L})\left(\mathrm{Y}_{2}\right)$ & $\begin{array}{l}\text { Weighted } \\
\text { response } \\
\text { (W) }\end{array}$ \\
\hline 1 & 35 & 25 & 3 & 5.6 & $6.74 \pm 1.20$ & $4.03 \pm 0.84$ & $\begin{array}{l}5.39 \pm \\
1.02\end{array}$ \\
\hline 2 & 35 & 25 & 3 & 7.6 & $6.95 \pm 0.86$ & $2.92 \pm 0.40$ & $\begin{array}{l}4.93 \pm \\
0.62\end{array}$ \\
\hline 3 & 35 & 25 & 3 & 5.6 & $7.42 \pm 0.36$ & $4.73 \pm 0.25$ & $\begin{array}{l}6.08 \pm \\
0.30\end{array}$ \\
\hline 4 & 35 & 40 & 3 & 6.6 & $2.30 \pm 0.23$ & $0.93 \pm 0.17$ & $\begin{array}{l}1.62 \pm \\
0.19\end{array}$ \\
\hline 5 & 35 & 10 & 3 & 6.6 & $2.95 \pm 0.53$ & $0.61 \pm 0.24$ & $\begin{array}{l}1.78 \pm \\
0.37\end{array}$ \\
\hline 6 & 35 & 25 & 3 & 6.6 & $2.46 \pm 0.17$ & $0.84 \pm 0.04$ & $\begin{array}{l}1.65 \pm \\
0.10\end{array}$ \\
\hline 7 & 35 & 25 & 3 & 6.6 & $2.27 \pm 0.54$ & $0.72 \pm 0.21$ & $\begin{array}{l}1.49 \pm \\
0.37\end{array}$ \\
\hline 8 & 35 & 25 & 5 & 6.6 & $7.95 \pm 0.56$ & $6.64 \pm 0.57$ & $\begin{array}{l}7.29 \pm \\
0.57\end{array}$ \\
\hline 9 & 35 & 25 & 3 & 6.6 & $3.03 \pm 0.60$ & $1.01 \pm 0.23$ & $\begin{array}{l}2.02 \pm \\
0.41\end{array}$ \\
\hline 10 & 35 & 25 & 3 & 6.6 & $2.76 \pm 0.88$ & $1.01 \pm 0.36$ & $\begin{array}{l}1.89 \pm \\
0.62\end{array}$ \\
\hline 11 & 35 & 25 & 3 & 7.6 & $7.47 \pm 1.10$ & $3.68 \pm 0.60$ & $\begin{array}{l}5.58 \pm \\
0.85\end{array}$ \\
\hline 12 & 35 & 25 & 1 & 6.6 & $2.38 \pm 0.28$ & $0.76 \pm 0.18$ & $\begin{array}{l}1.57 \pm \\
0.23\end{array}$ \\
\hline 13 & 35 & 25 & 5 & 6.6 & $8.25 \pm 0.94$ & $6.56 \pm 0.89$ & $\begin{array}{l}7.41 \pm \\
0.91\end{array}$ \\
\hline 14 & 35 & 25 & 1 & 6.6 & $2.40 \pm 0.24$ & $0.74 \pm 0.17$ & $\begin{array}{l}1.57 \pm \\
0.21\end{array}$ \\
\hline 15 & 35 & 10 & 3 & 6.6 & $2.94 \pm 0.55$ & $0.92 \pm 0.19$ & $\begin{array}{l}1.93 \pm \\
0.37\end{array}$ \\
\hline 16 & 35 & 40 & 3 & 6.6 & $2.89 \pm 0.10$ & $1.27 \pm 0.14$ & $\begin{array}{l}2.08 \pm \\
0.11\end{array}$ \\
\hline 17 & 25 & 34 & 2 & 7.2 & $4.15 \pm 0.36$ & $3.49 \pm 0.35$ & $3.82 \pm 0.35$ \\
\hline 18 & 25 & 34 & 4 & 6 & $1.85 \pm 0.07$ & $0.57 \pm 0.06$ & $1.21 \pm 0.06$ \\
\hline 19 & 25 & 16 & 4 & 6 & $2.52 \pm 0.08$ & $0.58 \pm 0.06$ & $1.55 \pm 0.07$ \\
\hline 20 & 25 & 25 & 3 & 6.6 & $7.04 \pm 1.03$ & $3.98 \pm 0.63$ & $5.51 \pm 0.83$ \\
\hline 21 & 25 & 25 & 3 & 6.6 & $5.34 \pm 0.56$ & $2.93 \pm 0.42$ & $4.14 \pm 0.49$ \\
\hline
\end{tabular}


Table Continued

\begin{tabular}{|c|c|c|c|c|c|c|c|}
\hline \multirow[b]{2}{*}{ Run order } & \multirow{2}{*}{$\begin{array}{l}\text { Block } \\
\text { Temperature }\left({ }^{\circ} \mathrm{C}\right)\end{array}$} & \multicolumn{3}{|c|}{ Experimental variables } & \multicolumn{3}{|l|}{ Responses } \\
\hline & & Glucose (g/L) & Yeast extract $(\mathrm{g} / \mathrm{L})$ & pH & Growth, CDW (g/L) $\left(Y_{1}\right)$ & $P(3 H B),(g / L)\left(Y_{2}\right)$ & $\begin{array}{l}\text { Weighted } \\
\text { response } \\
\text { (W) }\end{array}$ \\
\hline 22 & 25 & 34 & 2 & 6 & $2.45 \pm 0.20$ & $0.77 \pm 0.06$ & $1.61 \pm 0.13$ \\
\hline 23 & 25 & 16 & 2 & 7.2 & $2.93 \pm 0.19$ & $1.04 \pm 0.10$ & $1.98 \pm 0.14$ \\
\hline 24 & 25 & 16 & 2 & 6 & $2.52 \pm 0.18$ & $0.78 \pm 0.09$ & $1.65 \pm 0.13$ \\
\hline 25 & 25 & 25 & 3 & 6.6 & $6.57 \pm 0.19$ & $3.27 \pm 0.11$ & $4.92 \pm 0.14$ \\
\hline 26 & 25 & 25 & 3 & 6.6 & $5.50 \pm 0.95$ & $2.90 \pm 0.62$ & $4.20 \pm 0.78$ \\
\hline 27 & 25 & 16 & 2 & 6 & $2.19 \pm 0.05$ & $0.60 \pm 0.04$ & $1.39 \pm 0.04$ \\
\hline 28 & 25 & 25 & 3 & 6.6 & $6.91 \pm 1.15$ & $4.13 \pm 0.65$ & $5.52 \pm 0.90$ \\
\hline 29 & 25 & 16 & 4 & 6 & $2.55 \pm 0.16$ & $0.80 \pm 0.05$ & $1.68 \pm 0.10$ \\
\hline 30 & 25 & 16 & 4 & 7.2 & $5.21 \pm 0.30$ & $1.62 \pm 0.15$ & $3.42 \pm 0.18$ \\
\hline 31 & 25 & 25 & 3 & 6.6 & $6.11 \pm 0.36$ & $3.30 \pm 0.22$ & $4.71 \pm 0.28$ \\
\hline 32 & 25 & 34 & 4 & 6 & $2.65 \pm 0.06$ & $0.89 \pm 0.06$ & $1.77 \pm 0.05$ \\
\hline 33 & 25 & 34 & 2 & 7.2 & $3.41 \pm 0.30$ & $2.78 \pm 0.20$ & $3.10 \pm 0.25$ \\
\hline 34 & 25 & 25 & 3 & 6.6 & $5.11 \pm 0.33$ & $2.76 \pm 0.19$ & $3.93 \pm 0.24$ \\
\hline 35 & 25 & 34 & 4 & 7.2 & $10.35 \pm 0.19$ & $8.03 \pm 0.24$ & $9.19 \pm 0.19$ \\
\hline 36 & 25 & 16 & 4 & 7.2 & $6.40 \pm 0.50$ & $4.67 \pm 0.43$ & $5.54 \pm 0.47$ \\
\hline 37 & 25 & 16 & 2 & 7.2 & $6.38 \pm 0.20$ & $4.62 \pm 0.14$ & $5.50 \pm 0.17$ \\
\hline 38 & 25 & 34 & 4 & 7.2 & $9.90 \pm 0.37$ & $7.95 \pm 0.31$ & $8.92 \pm 0.32$ \\
\hline 39 & 25 & 25 & 3 & 6.6 & $5.02 \pm 0.63$ & $2.90 \pm 0.33$ & $3.96 \pm 0.48$ \\
\hline 40 & 25 & 34 & 2 & 6 & $3.01 \pm 0.45$ & $0.95 \pm 0.16$ & $1.98 \pm 0.30$ \\
\hline
\end{tabular}

Each experimental value represents the mean \pm standard deviation from 5 replicates. 
Table 5 Analysis of variance for weighted response (W) based on central composite design of response surface methodology

\begin{tabular}{lllllll}
\hline Source & DF & Seq SS & Adj SS & Adj MS & F value & p value \\
\hline Blocks & 1 & 2.35 & 2.393 & 2.3932 & 0.84 & 0.368 \\
Regression & 9 & 117.394 & 117.394 & 13.0438 & 4.56 & 0.001 \\
Linear & 3 & 70.743 & 70.743 & 23.581 & 8.25 & 0 \\
Square & 3 & 26.516 & 26.516 & 8.8388 & 3.09 & 0.042 \\
Interaction & 3 & 20.135 & 20.135 & 6.7115 & 2.35 & 0.093 \\
Residual error & 29 & 82.931 & 82.931 & 2.8597 & & \\
Lack of fit & 5 & 63.005 & 63.005 & 12.6009 & 15.18 & 0 \\
Pure error & 24 & 19.926 & 19.926 & 0.8303 & & \\
Total & 39 & 202.674 & & & &
\end{tabular}

DF, degree of freedom; Seq SS, sequential sum of squares, Adj SS, adjacent sum of squares; Adj MS, adjacent mean square

R-Squared=89.08\%; R-Squared (adjusted) $=84.97 \%$

Table 6 Confirmatory trials for the predicted responses under optimal conditions

\begin{tabular}{llll}
\hline Responses & Predicted value & Experimental value & Confidence interval (95\%) \\
\hline Weighted response $(\mathrm{W})$ & 9.1 & $9.16 \pm 0.31$ & $(8.94,9.38)$ \\
Growth, $\mathrm{CDW}, \mathrm{g} / \mathrm{L}\left(\mathrm{Y}_{1}\right)$ & 10.55 & $10.25 \pm 0.48$ & $(9.90,10.59)$ \\
$\mathrm{P}(3 \mathrm{HB}), \mathrm{g} / \mathrm{L}\left(\mathrm{Y}_{2}\right)$ & 7.8 & $8.07 \pm 0.16$ & $(7.96,8.19)$ \\
\hline
\end{tabular}

Each experimental value represents the mean \pm standard deviation from 10 replicates.

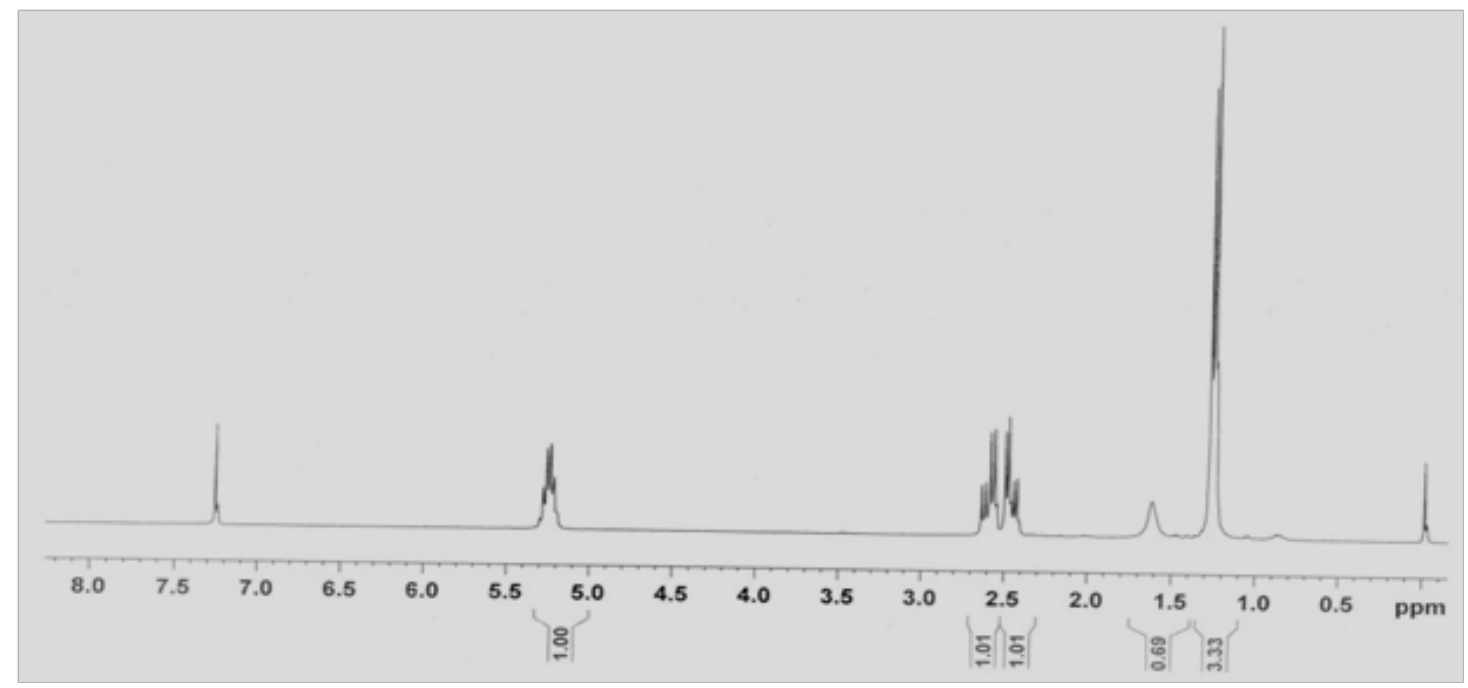

Figure 4IH NMR spectra of the purified intracellular polyester extracted from the endophytic bacterial isolate B. cereus RCL 02 .

\section{Conclusion}

The present study, first of its kind, clearly demonstrated the interactive effects of carbon, nitrogen and initial $\mathrm{pH}$ on growth as well as $\mathrm{P}(3 \mathrm{HB})$ production by $B$. cereus RCL 02 endophytic to $R$. communis $\mathrm{L}$. following the weighted response surface methodology. The resultant weighted response (W) of the two individual dependent responses, growth $\left(\mathrm{Y}_{1}\right)$ and polyester production $\left(\mathrm{Y}_{2}\right)$ has been successfully implemented in modeling and studying interaction of the independent variables for maximum biomass and biopolyester production. Statistical analysis of the experimental findings clearly revealed that the actual production of $\mathrm{P}(3 \mathrm{HB})$ by the strain $(8.07 \mathrm{~g} / \mathrm{L})$ was higher than that of the predicted value $(7.8 \mathrm{~g} / \mathrm{L})$ and thereby validated the applied model. Further scale up studies using the optimized media formulation and the cost effective non conventional carbon sources for the production of biopolyester by B. cereus RCL 02 are under progress.

\section{Acknowledgements}

Research support to Rituparna Das from the Department of Science and Technology, New Delhi, India (Grant No. DST/INSPIRE Fellowship/REL3/2013/2) is duly acknowledged. 


\section{Conflict of interest}

The author declares no conflict of interest exists.

\section{References}

1. Braunegg G, Lefebvre G, Genser KF. Polyhydroxyalkanoates, biopolyesters from renewable resources: physiological and engineering aspects. J Biotechnol. 1998;65(2-3):127-161.

2. Wu Q, Huang H, Hu G, et al. Production of poly-3-hydroxybutyrate by Bacillus sp. JMa5 cultivated in molasses media. Antonie Van Leeuwenhoek. 2001;80(2):111-118.

3. Valappil SP, Misra SK, Boccaccini AR, et al. Large-scale production and efficient recovery of PHB with desirable material properties, from the newly characterized Bacillus cereus SPV. J Biotechnol. 2007;132(3):251258.

4. Khanna S, Srivastava AK. Statistical media optimization studies for growth and PHB production by Ralstonia eutropha. Process Biochemistry. 2005;40(6):2173-2182.

5. Aramvash Z, Shahabi SA, Aghjeh D, et al. Statistical physical and nutrient optimization of bioplastic polyhydroxybutyrate production by Cupriavidus necator. International Journal of Environmental Science and Technology. 2015;12(7):2307-2316.

6. Sindhu R, Silviya N, Binod P, et al. Pentose-rich hydrolysate from acid pretreated rice straw as a carbon source for the production of poly-3hydroxybutyrate. Biochemical Engineering Journal. 2013;78:67-72.

7. Sharma P, Bajaj BK. Production of poly- $\beta$-hydroxybutyrate by Bacillus cereus PS 10 using biphasic-acid-pretreated rice straw. Int $\mathrm{J}$ Biol Macromol. 2015;79:704-710.

8. Madhumathi R, Muthukumar K, Velan M. Optimization of polyhydroxybutyrate production by Bacillus safensis EBT1. Clean Soil Air Water. 2016;44(8):1066-1074

9. Ramsay BA, Lomaliza K, Chavarie C, et al. Production of poly( $\beta$-hydroxybutyric-co- $\beta$-valeric) acids. Appl Environ Microbiol. 1990;56(7):2093-2098.

10. Law JH, Slepecky RA. Assay of polyhydroxybutyric acid. J Bacteriol. 1961;82(1):32-36.
11. Das R, PalA, Paul AK. Production of biopolyester poly(3-hydroxybutyrate) by Bacillus cereus RCL 02, a leaf endophyte of Ricinus communis L. J Microbiol Biotech Res. 2017;7(4):32-41.

12. Doi Y, Kawaguchi Y, Nakamura Y, et al. Nuclear magnetic resonance studies of poly(3-hyroxybutyrate) and polyphosphate metabolism in Alcaligenes eutrophus. Appl Environ Microbiol. 1989;55(11):2932-2938.

13. Ribeiro JS, Teófilo RF, Augusto F, et al. Simultaneous optimization of the microextraction of coffee volatiles using response surface methodology and principal component analysis. Chemometrics and Intelligent Laboratory Systems. 2010;102(1):45-52.

14. Khuri AI, Cornell JA. Response surfaces designs and analyses Marcel Dekker. New York, USA: ASQC quality press; $1987 .$.

15. Mokhtari-Hosseini ZB, Vasheghani-Farahani E, HeidarzadehVazifekhoran A, et al. Statistical media optimization for growth and PHB production from methanol by a methylotrophic bacterium. Bioresour Technol. 2009;100(8):2436-2443.

16. Page WJ. Production of poly- $\beta$-hydroxybutyrate by Azotobacter vinelandii UWD in media containing sugars and complex nitrogen sources. Applied Microbiology and Biotechnology. 1992;38(1):117-121.

17. Narayanan A, Ramana KV. Polyhydroxybutyrate production in Bacillus mycoides DFC1 using response surface optimization for physico-chemical process parameters. 3 Biotech. 2012;2(4):287-296.

18. Sathiyanarayanan G, Saibaba G, Kiran GS, et al. A statistical approach for optimization of polyhydroxybutyrate production by marine Bacillus subtilis MSBN17. International Journal of Biological Macromolecules. 2013;59:170-177.

19. Pandian SR, Deepak V, Kalishwaralal K, et al. Optimization and fed-batch production of PHB utilizing dairy waste and sea water as nutrient sources by Bacillus megaterium SRKP-3. Bioresour Technol. 2010;101(2):705711

20. Tripathi AD, Srivastava SK, Singh RP. Statistical optimization of physical process variables for bio-plastic (PHB) production by Alcaligenes $s p$ Biomass and Bioenergy. 2013;55:243-250.

21. Vijayendra SV, Rastogi NK, Shamala TR, et al. Optimization of polyhydroxybutyrate production by Bacillus sp. CFR 256 with corn steep liquor as a nitrogen source. Indian J Microbiol. 2007;47(2):170-175. 